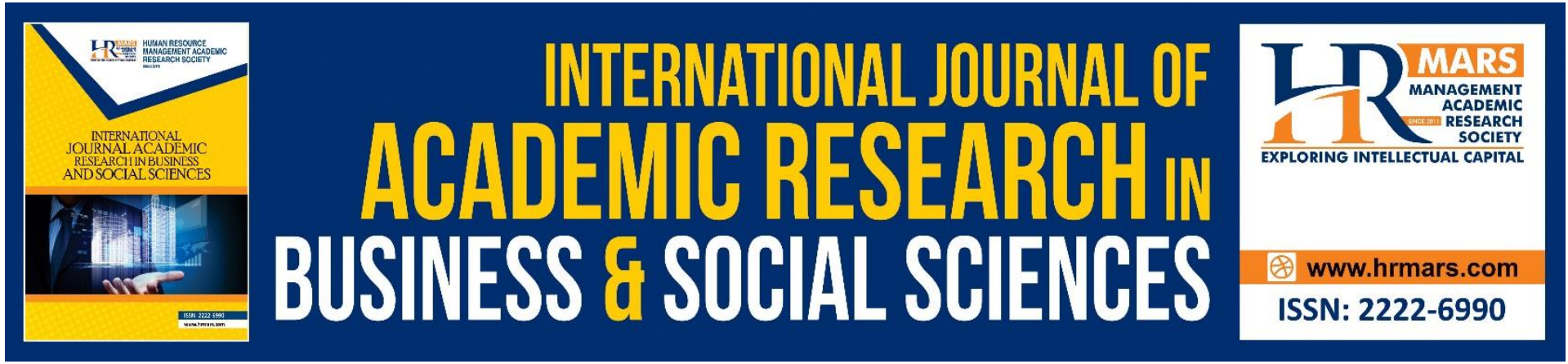

\title{
Survey of Perception on Online Learning among Low- Income Group Students in Pre-Diploma Programs
}

Siti Nurleena Abu Mansor, Mahanim Omar and Siti Mariam Saad

To Link this Article: http://dx.doi.org/10.6007/IJARBSS/v11-i9/11076

DOI:10.6007/IJARBSS/v11-i9/11076

Received: 02 July 2021, Revised: 29 July 2021, Accepted: 17 August 2021

Published Online: 11 September 2021

In-Text Citation: (Mansor et al., 2021)

To Cite this Article: Mansor, S. N. A., Omar, M., \& Saad, S. M. (2021). Survey of Perception on Online Learning among Low-Income Group Students in Pre-Diploma Programs. International Journal of Academic Research in Business and Social Sciences, 11(9), 873-887.

Copyright: (c) 2021 The Author(s)

Published by Human Resource Management Academic Research Society (www.hrmars.com)

This article is published under the Creative Commons Attribution (CC BY 4.0) license. Anyone may reproduce, distribute, translate and create derivative works of this article (for both commercial and non-commercial purposes), subject to full attribution to the original publication and authors. The full terms of this license may be seen at: http://creativecommons.org/licences/by/4.0/legalcode

Vol. 11, No. 9, 2021, Pg. 873 - 887

http://hrmars.com/index.php/pages/detail/IJARBSS

JOURNAL HOMEPAGE

Full Terms \& Conditions of access and use can be found at

http://hrmars.com/index.php/pages/detail/publication-ethics 


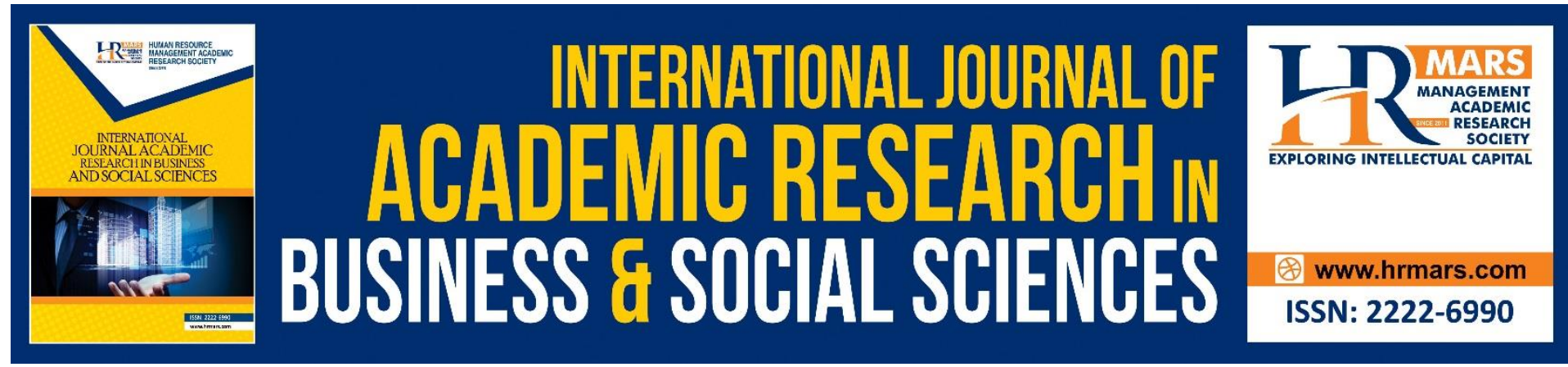

\title{
Survey of Perception on Online Learning among Low-Income Group Students in Pre-Diploma Programs
}

\section{Siti Nurleena Abu Mansor, Mahanim Omar and Siti Mariam Saad}

Department of Computer and Mathematical Sciences, Universiti Teknologi MARA, Cawangan Pulau Pinang, Kampus Permatang Pauh, 13500 Pulau Pinang, Malaysia

\begin{abstract}
Over a year has passed after the massive transition of face-to-face teaching and learning (TL) to online learning (OL) due to the Covid-19 pandemic. Upon this date, OL has become a common practice for primary, secondary, and even tertiary education. This sudden change affects all students from each level of income groups, no exception to the low-income families. The hardship they endure during the pandemic not only to survive the retrenchment but also persisting their children education. The low-income group students must compete between all equipped students, with themselves whom barely have a computer. The aim of the study was to evaluate the low-income and non-low-income students on their perception on $\mathrm{OL}$ and the supports they received from their families and instructors. Data were collected from 206 pre diploma students in UiTM Cawangan Pulau Pinang, on their first-time OL experiences. The data analysis was done on the descriptive (presented in tables and diagrams) and inferential statistics (t-test analysis and chi-square test). Findings indicated that majority of the students received enough support from their families and instructors. However, almost half of the students, either in the low-income group or not, sometimes experienced problems with internet connection and internet data. Furthermore, a few low-income students' families have been affected by the Movement Control Order (MCO), requiring them to balance their time between studying and helping their families. Even though only few students from lowincome group admitted to having a problem with $\mathrm{OL}$, more than half of students from both groups do sometimes have problems with $\mathrm{OL}$ should not be overlooked. Prolonging this condition can cause difficulties in their studies.
\end{abstract}

Keywords: Covid 19, Family Support, Online Learning, Perception, Student's Experience.

\section{Introduction}

Online learning (OL) has been a part of educational systems since the 1800 s, when it was first implemented at the University of Chicago. OL provides opportunities for open access education and training without requiring teachers and students to be in the same place (Brindley, 1995). The development of technology in education has led to widespread acceptance and innovation of OL (Ghosh, 2012; Swart, 2015; Makoe \& Shandu, 2018). 
Drastically, due to the Covid-19 pandemic, the entire educational system seemed to undergo a significant transition to $\mathrm{OL}$. It has been the greatest challenge for many countries at the point that they need to radically change their traditional teaching methods to $\mathrm{OL}$ following the lockdown by the government (Daniel, 2020). Lassoued, et al. (2020) explored the obstacles to achieving quality in OL for higher education institutions during the pandemic, and the authors suggested the need for improved infrastructure, prepared electronic courses, training, and, most importantly, providing internet access to all students.

Appolloni et al (2020) demonstrated that higher education in Italy could implement OL in a short period of time by combining quality in education and technology devices to ensure continuity of education during the Covid-19 pandemic. Furthermore, in the current circumstances, there is the possibility of delivering effective OL using open educational resources and open educational practices (Huang et al., 2020). To cope with the changes, teachers need better OL instructional training as part of their professional development to ensure that they can deliver OL effectively (Marek et al., 2021). Students, on the other hand, are looking forward to adapting OL by utilising the technology in education and changes in pedagogy strategies in the future (Amir et al., 2020).

Nevertheless, lower income families may face difficulties providing their children with the necessities required for $\mathrm{OL}$, such as smartphones, laptops, sufficient internet data, and so forth (Pityana, 2009; Firat \& Bozkurt, 2020; Selvaras, 2020). During the crisis, a developing country like India tries to ensure education for all by using $\mathrm{OL}$, despite facing many challenges in technology infrastructure and inexperienced parents and teachers (Jena, 2020). Malaysia, without exception, faced the same challenges, with fourty percent of the population are from the low-income group (B40) (Chin et al., 2020; Ramli et al., 2020). As a result, the aim of this study is to assess the experiences of low-income (B40) and non-low-income (Non-B40) students with $\mathrm{OL}$, as well as the support they received from their families and instructors, based on their first experience with it.

\section{Literature Review}

\section{Family' Supports}

The fear of the Covid-19 pandemic has resulted in the closure of physical classes, either for school children or higher institution students. Students are forced to use a variety of devices such as computers, laptops, tablets, and mobile phones with internet access for online learning. For students from the low-income group, this situation is very challenging. They need to have at least one device and a stable internet connection. Not only that, they need to have a proper place or environment to attend their online learning class.

\section{a. Family's Understanding towards $O L$}

Students' persistence in online courses is influenced by several personal factors, including satisfaction with the courses or a sense of achievement, personal aspirations, a sense of community and belonging, family support, and time management skills (Hart, 2012). Usually, students' desire to persist in online programmes, is often affected by their ability to pay for the programme and obtain sufficient support from families, friends, and employers (such as childcare and flexible work schedule) (Ivankova \& Stick, 2007).

Support from families, friends and employers also helps online students manage their time better, which is essential for completing the necessary coursework. The flexibility and convenience of online programs help students persist while balancing work and family (Müller, 2008). Encouragement and support from family members are important source of 
motivation. In a study by Rolè (2014), from thirty-seven students, there was one student with family problem and being emotionally low. This student felt falling behind for almost three months.

In a study of the effects of online home-schooling on children, parents, and teachers, $50 \%$ of parents believed that monitoring was required during online classes, with the percentage decreasing as the grades increased (Zhao et. al, 2020). This cannot be implemented if the parents are working. In order to help parents and students cope with online learning, UNESCO release a "Guidance on active learning at home during educational disruption: promoting student's self-regulation skills during COVID-19 outbreak" for reference.

\section{b. Financial for Devices and Connection}

According to the results of a poll conducted by the Ministry of Education (MOE) Malaysia, involving nearly 900,000 students, 37 percent of students do not have access to adequate devices. At the same time, only $6 \%$ to $9 \%$ of students have access to a personal computer or tablet (Hawati \& Jarud, 2020). With the increased rate of unemployment rate from 3.3 percent on February 2019 to 4.7 percent on August 2020 (Department of Statistics Malaysia, 2020), many families are experiencing financial difficulties. In difficult times, poorer families are more likely to prefer putting food on the table over buying digital devices and acquiring internet access. There is a call for the government to act quickly with the distribution of 150,000 free laptops for students in 500 schools under the Cerdik Fund declared in Budget 2021 (Nordin, 2021).

\section{c. Proper Study Environment}

One of the techniques for Active Learning at home is parents need to prepare a quite environment or proper place for the learning process (UNESCO Institute, 2020). However, for some students, this is not possible since they live in a small house with several siblings who are also participating in online learning.

Rolè (2014) reported the following findings in his study:

I. the computer was placed in a noisy area in the house (4 students).

II. the computer was used by other members in the family (5 students).

III. a limited time for Internet use was imposed by parents (3 students).

IV. a limited time due to expensive dial-up connection (1 students).

V. poor connectivity and an outdated computer system (1 students).

It shows that the academic performance of university students can be affected by the environmental conditions. Students need good level of lighting, in conjunction with proper ventilation. In addition, higher level of noise at home, indicate a higher level of distraction while taking online classes (Realyvásquez-Vargas, 2020).

\section{Instructors' Supports}

\section{a. Instructors' Understanding Towards Students During $O L$}

The first concern raised by the implementation of online learning is that it is only available to students who have access to a fast enough broadband connection at home. Students with insufficient equipment, such as weak internet connections, lack of adequate digital devices, and unconducive environments, struggled to adjust online learning, especially those from low-income families. If this persists for an extended period of time, students may lose motivation adapting to new learning. 
Teachers, in addition to parents, play an important role in inspiring and empowering students to overcome obstacles during online learning. If they faced problems and no answers can be found, the least teachers can do is be compassionate, understand their circumstances, and refrain from punishing them. As per Coman et al (2020), teachers who respond with phrases like "there is nothing I can help you" or "it is your problem" would only demotivate students, increase their frustration, and increase their risk of dropping out.

\section{b. OL Platforms and Materials}

Aside from understanding students' conditions during online learning, teachers should carefully plan their lessons and consider learning tools that are convenient for the online learning environment. Students can gain the most from the learning process if they can use effective learning tools to find and process information, respond to their understanding, and thus focus on their own learning (Ismail et al., 2020). According to the findings of Coman et al (2020), it is necessary to use the video conference function during classes, to balance the number of theory and practical tasks, and to assign students a sufficient number of practical tasks for better information assimilation. However, for students who are unable to join the video conference, teachers must include information in a variety of formats, such as video, audio, and text. This implies that teachers must diversify their teaching styles and approaches in order to appeal to all types of student circumstances (Arumugam, 2020). Concerning the assigned practical tasks, it is necessary for teachers to immediately provide feedback on the tasks completed by students to avoid them from becoming lost or uncertain (Coman et al., 2020).

\section{c. Instructor's Concern on Students}

Instructor's mental and emotional support are just as vital as parental support in helping students remain focused on their online learning and maintain their enthusiasm and attitudes toward learning (Arumugam, 2020). As Coman et al (2020) pointed out, teachers must know how to build interactions and relationships with students because they can feel isolated due to the lack of physical peers during online learning. A study by Kim and Lee (2011) compared blended and online learning outcomes for 1,943 Korean students, 915 of whom were identified as lower-income students, and discovered that students who experienced online learning supported by a homeroom teacher (blended condition) demonstrated high levels of learning satisfaction when compared to students who self-study without the assistance of any teachers (fully online condition). Students in the blended learning condition learned more as a result of their teachers' real-time support and encouragement. This shows the significance of instructors providing support to students in order to ensure successful learning.

\section{Methodology}

The aim of this paper is to analyse the association between students' perception on online learning based on their expirenced among students. Their perception were compared among two groups, low-income (B40) and non-low-income (Non-B40) groups.

\section{Respondents and Data Collection}

Data was collected in November 2020 using a self-administered online questionnaire through online platform, WhatsApp. Systematic random sampling was used so that every prediploma student has the same chance of being included in the survey. This cross-sectional 
study was used to explore the pre diploma students' first-time experience on OL based on the availability of supports from their family and instructors. The respondents in this study were 206 pre diploma students, registered in Pre-Diploma Science program (PD007 and PD008) and Pre-Diploma Commerce program (BA002 and BA003), in Universiti Teknologi MARA Cawangan Pulau Pinang. Respondents were grouped based on low-income (B40) and nonlow-income (Non-B40) families.

\section{Data Analysis}

The study design is a descriptive and inferential statistical analysis. First, the descriptive statistics were calculated, and the results were presented in tables and figures. The chi-square test was used to discover if there was any association between category (B40 vs. non-B40 students) and their OL experience. Next, the score for instructors' support and family's support was calculated based on three selected questions for each category (5-Likert scales type answer, $1=$ Strongly not agree to $5=$ Strongly agree). The total score of 3 to 6 indicated less support, a score of 7 to 11 indicated average support, and a score of 12 to 15 indicated good support. Independent samples t-test was used to compare the means of score between the two groups (B40 and non-B40) for instructors and family support. This test was done to understand whether the support students received from instructors and their families during $\mathrm{OL}$ were differed based on the group.

\section{Questionnaire Development}

The questionnaire development was organised and adopt from a number of literature reviews. It has demographic and close-ended questions (5-Likert scales: Strongly agree to strongly disagree). The questionnaire has three main sections, (1) students' OL experience, (2) support from instructors in OL, and (3) support from family in OL. There were 14 questions in total and written in English.

There are four items for students' OL experience (Bernard et al., 2004; Moore et al., 2011), five items for support from teachers in OL (Lee et al., 2011; Nambiar, 2020), and five items for support from family in OL (Rahmadian \& Maksum, 2021), as shown in Table 1. Cronbach's alpha for each factor was 0.881 for students' OL experience, 0.832 for support from teachers in OL, and 0.811 for support from family in OL. 
Table 1. Student's perception on online learning instruments

\begin{tabular}{|c|c|c|}
\hline Factor & No. & Items \\
\hline \multirow{4}{*}{$\begin{array}{l}\text { Factor 1: } \\
\text { Students experienced } \\
\text { with online learning }\end{array}$} & 1 & $\begin{array}{l}\text { Do you think you have sufficient internet data for online } \\
\text { learning? }\end{array}$ \\
\hline & 2 & $\begin{array}{l}\text { Do you have problem downloading notes from your } \\
\text { instructors? }\end{array}$ \\
\hline & 3 & $\begin{array}{l}\text { Do you have problem downloading lecture videos from your } \\
\text { instructors? }\end{array}$ \\
\hline & 4 & Overall, do you have problem with online learning? \\
\hline \multirow{5}{*}{$\begin{array}{l}\text { Factor 2: } \\
\text { Instructor's support }\end{array}$} & 5 & Instructors really help the students with online learning. \\
\hline & 6 & Instructors try to understand your condition. \\
\hline & 7 & $\begin{array}{l}\text { Instructors give many learning materials (notes, handouts, } \\
\text { etc.) in order to help you with online learning. }\end{array}$ \\
\hline & 8 & Instructors always cared about your wellbeing. \\
\hline & 9 & Instructors always answer your questions online. \\
\hline \multirow[t]{5}{*}{$\begin{array}{l}\text { Factor 3: } \\
\text { Family's support }\end{array}$} & 10 & $\begin{array}{l}\text { My family is affected by the movement control order (MCO) } \\
\text { during Covid-19 pandemic. }\end{array}$ \\
\hline & 11 & I need to help my family during MCO. \\
\hline & 12 & MCO halt me to do my online learning. \\
\hline & 13 & My family give fully support during my online learning. \\
\hline & 14 & My home is conducive for my online learning. \\
\hline
\end{tabular}

\section{Results and Discussion}

Presented are the descriptive results from data collection. Results in Table 2 indicates the total number of students who involved in the study, divided by gender and programs. There was a total of 130 students from the B40 family, and the program was denoted by BA002 and PD007, while 76 students from the non-B40 family were denoted by BA003 and PD008.

Table 2. Distribution of B40 and non-B40 group of students

\begin{tabular}{lll|ll|l}
\hline & B40 & & Non-B40 & \multirow{2}{*}{ Overall } \\
\cline { 2 - 5 } & BA002 & PD007 & BA003 & PD008 & \\
\hline Male & 30 & 5 & 21 & 9 & 65 \\
Female & 69 & 26 & 38 & 8 & 141 \\
\hline TOTAL & 130 & & 76 & & 206 \\
\hline
\end{tabular}

The results from Table 3 indicated that $51 \%$ of B40 students admitted they sometimes had sufficient internet data and there were $23 \%$ of them had insufficient internet data. Therefore, they always or sometimes had problem in downloading notes (52\%) and videos (54\%). Non-B40 students also have problem with insufficient internet data (17\%) or sometimes have insufficient data (39\%). However, most of them had no problem with downloading notes (64\%) and videos (69\%). Insufficient internet data is very common problem among students. In study done by Al-Kumaim et al (2021), more than $51 \%$ of the respondents stated that they have limited and weak internet connection. 
Table 3 also shows that in overall, there are only $3 \%$ of students in the B40 group admitted that they did had a problem learning using OL, while no students in the non-B40 group had a problem with OL. More than half of the students noted that they sometimes had problem with OL (B40 - 53\% and non-B40-51\%). Based on the results, internet data could be one of the factors that contributed to the students' OL problem. This result is consistent with the findings of Ismail, Abu Bakar, and Syed Saadun Tarek Wafa (2020), who found that one of the most common concerns raised by students at a local university on Peninsular Malaysia's east coast as limiting online learning sessions is the speed of the internet connection. However, nearly half of the students from each group (B40 - 44\% and non-B4049\%) did not faced any problem with OL.

Table 3. OL experiences by categories B40 and non-B40

\begin{tabular}{lccc}
\hline & Yes (\%) & $\begin{array}{c}\text { Sometimes } \\
(\%)\end{array}$ & No (\%) \\
\hline $\begin{array}{l}\text { Have sufficient internet data. } \\
\text { B40 }\end{array}$ & 26 & 51 & 23 \\
Non-B40 & 44 & 39 & 17 \\
Have problem in downloading notes. & 2 & 50 & 48 \\
B40 & 7 & 29 & 64 \\
Non-B40 & & & \\
Have problem in downloading videos. & 4 & 50 & 46 \\
$\quad$ Non-B40 & 4 & 27 & 69 \\
Overall, students are having problem with & & & \\
online learning. & 3 & 53 & 44 \\
B40 & & 51 & 49
\end{tabular}

Despite half of the students had problem with OL (Figure 1), 54\% strongly agreed (while another $34 \%$ agreed) that their instructors understood their students' difficulties with OL. Instructors gave their best to help the students by providing appropriate materials in making sure the students could participate in OL. 49\% of students strongly agreed (while another $38 \%$ agreed) that instructors did provide them with sufficient notes and videos each week during the semester. 
Figure 1. Instructor's effort in helping the students through online learning
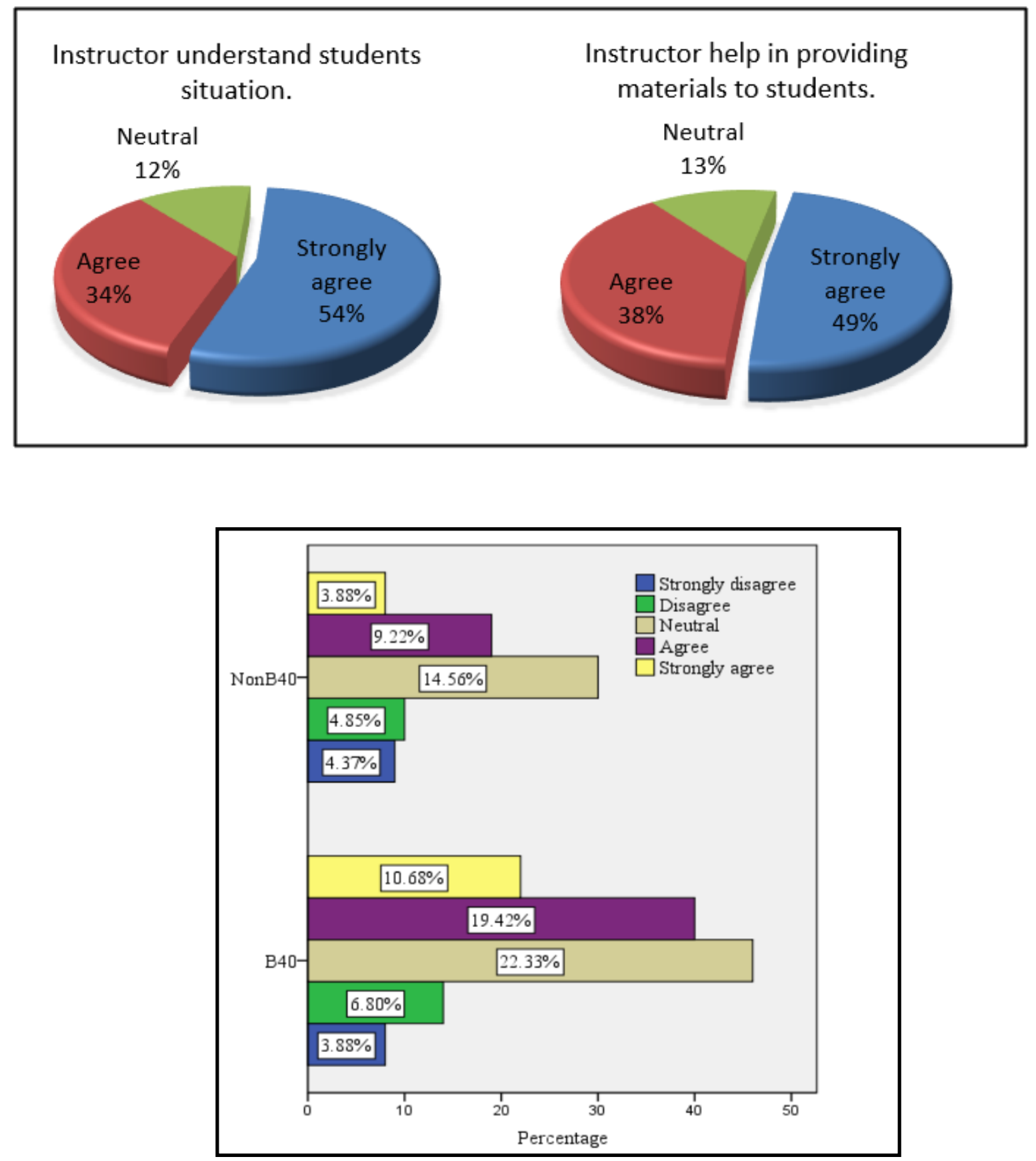

Figure 2. Covid 19 affected family by group categories

Figure 2 reveals that 10.68\% (B40) and 3.88\% (Non-B40) of the students did strongly agreed that their families had been affected by the movement control order (MCO) done by the government to halt the pandemic. This implies that their family might be economically decline (retrenchment, business closure, unpaid work, etc.) or having health issues. Furthermore, $34 \%$ of them ( $\mathrm{B} 40-22 \%$ and non-B40 - 12\%) admitted that they needed to give a hand and support their family during the stay-at-home period even though at the same time they had to participate in OL (Figure 3). From both figures, the B40 students had higher percentage compared to the non-B40 students. 
These findings raise the most concern about the performance of students who are dealing with family issues at home. Their performance would suffer substantially since they would be unable to focus completely on their online learning, as opposed to before the pandemic when students had face-to-face classes on campus and were less distracted by family difficulties. This also supported by Al-Kumaim et al (2021) where half of the respondents find difficult and challenge to pay attention to their study while being with family during lockdown.

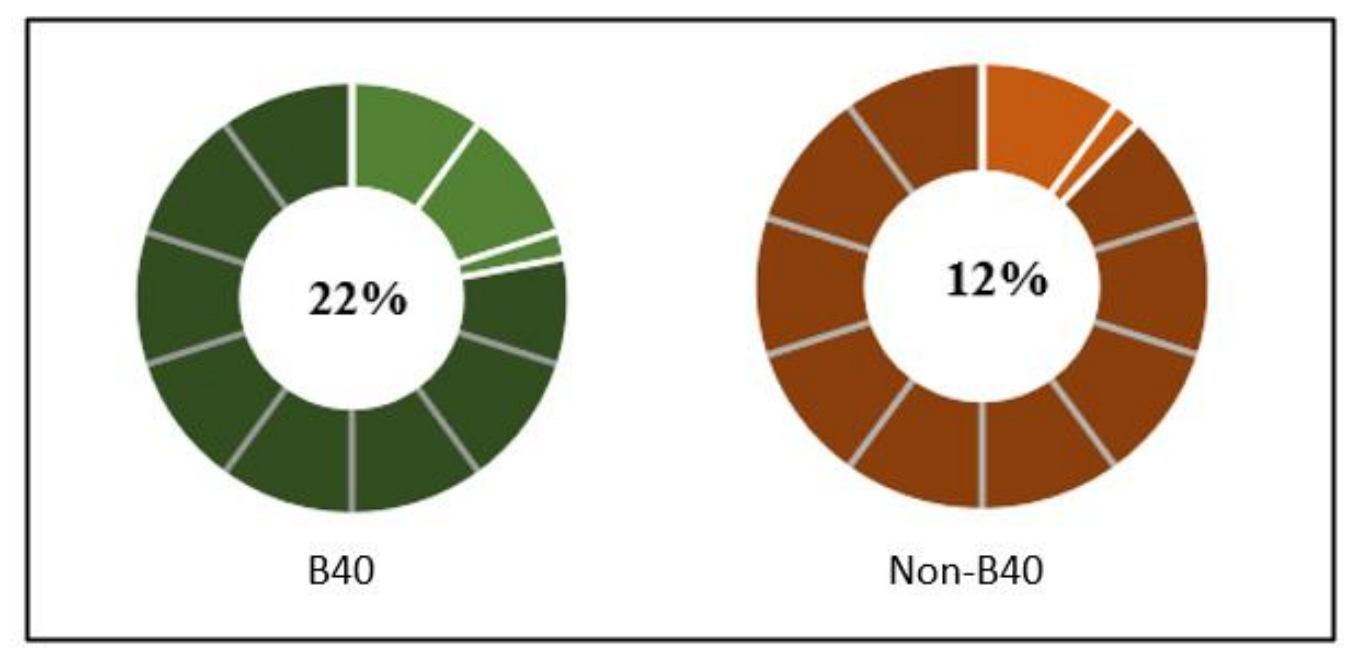

Figure 3. Students needed to help family during the pandemic

Based on earlier results, B40 students seemed to be more affected by the pandemic situation that led to the problems with OL. Since the study is of two variables which is students' group (B40 or non-B40) and experienced problem in OL, chi-square test was used to test for association between these variables. Table 4 shows the chi-square results. The chisquare statistic is equal to 1.875 with $p$-value equal to 0.392 . Therefore, the result is not significant as the $p$-value is greater than 0.05 . This means that there is no association between the two groups and experienced problems in OL.

Table 4. ODL experiences by categories B40 and Non-B40

\begin{tabular}{llll}
\hline & Value & df & $\begin{array}{l}\text { Asymptotic } \\
\text { Significance } \\
\text { (2-sided) }\end{array}$ \\
\hline Pearson Chi-square & 1.875 & 2 & 0.392 \\
Likelihood Ratio & 2.883 & 2 & .237 \\
N of Valid Cases & 206 & & \\
\hline
\end{tabular}

Next, the study explored the support student received from their instructors and family regarding OL. Refers to Table 5, the total score of instructors' support and family's support were grouped into three classes: less (score 3-6), average (score 7-11), and good (score 12-15). Most students indicated that they received good support from the instructors (B40-83\% and non-B40-87\%). However, there were slight difference in family's support, where only $59 \%$ of $\mathrm{B} 40$ students receiving good support compared to $75 \%$ of non-B40 students. There were also $9 \%$ of students from B40 and 2\% from non-B40 claimed that they got less support from their family during OL. This could be because parents who had multiple 
children engaged in online learning at the same time during the MCO were unable to provide full support to each child. In a study done on parents (Garbe et al., 2020), many respondents struggle to balance their responsibilities which are their employment demand and assisting their children with online learning. It is very understandable that children at higher education institutions get less parental support since their parents think they are more mature and capable of coping on their own. Families who experienced financial hardships as a result of the pandemic, which impacted $30.1 \%$ of the B40 students in this study, may have had less time to care about their children's education as they struggled to make ends meet.

Table 5. Support on ODL by categories B40 and non-B40

\begin{tabular}{ll|lll}
\hline \multicolumn{5}{c}{ Support on ODL } \\
\hline \multirow{2}{*}{ Instructors } & B40 & $83 \%$ & $17 \%$ & $0 \%$ \\
& Non-B40 & $87 \%$ & $13 \%$ & $0 \%$ \\
\hline \multirow{2}{*}{ Family } & B40 & $59 \%$ & $32 \%$ & $9 \%$ \\
& Non-B40 & $75 \%$ & $23 \%$ & $2 \%$ \\
\hline
\end{tabular}

Independent samples t-test was used to compare means of each score between the two groups (B40 and non-B40) for instructors' support and family's support. This test was done to understand whether the support that students received from instructors and their family during ODL were differed based on group. Table 5 shows the result, there was no significance difference in mean score for instructors' support ( $t_{\text {instructor }}=-1.288, p>0.05$ ) and family's support ( $t_{\text {family }}=-0.895, p>0.05$ ) between $B 40$ and non-B40 groups.

Table 5. Independent t-test

\begin{tabular}{lccl}
\hline & Value & Df & $\begin{array}{l}\text { Asymptotic } \\
\text { Significance } \\
\text { (2-sided) }\end{array}$ \\
\hline Instructors' support & -1.288 & 204 & 0.199 \\
Family's support & -0.895 & 204 & 0.372 \\
\hline
\end{tabular}

After going through the results, sufficient internet data is important in making sure the implementation of OL is a success (Mathew \& Chung, 2020). Students faced with insufficient data could not receive material from their teachers even how good the material was. All the instructors' efforts would be wasted, and the students could not get benefits from it. B40 students were the most affected, perhaps because of constraints in expenses for internet data subscription and appropriate devices (Mbatha \& Naidoo, 2010; Mavromatis, 2018). Not only that, poor internet coverage faced by students who live in remote areas could hinder them from participating in online class. As suggested by Ismail, Abu Bakar, and Syed Saadun Tarek Wafa (2020), all major telecommunications service providers should upgrade and boost their network infrastructure nationally, as well as lower the internet access cost, to ensure that all students can access the internet at a low cost. This will help to reduce the educational gap caused by diverse socioeconomic backgrounds.

Although only a small number of B40 students admitted that they really had a problem with OL (3\%), students who admitted to having a problem occasionally could not be ignored. This condition could halt students' interest in OL which lead them to have difficulties in their studies (Mbatha \& Naidoo, 2010; Musingafi et al., 2015; Virtic et al., 2021). Solid support 
systems from schools/universities, instructors, families, society and the government should be in place to ensure that every student, regardless of background, can receive quality online education despite the pandemic. Even though there were differences from the observation of results, indicated by group B40 and non-B40 in sufficient internet data and problems with $\mathrm{OL}$, statistical analysis indicated that there was no difference between these two groups and supports from instructors and family.

\section{Conclusion}

Based on the results and discussion, undoubtedly students from any group receive good support from their instructors. Instructors in anyway have tried to provide appropriate materials and to respond to student questions as soon as possible to ensure that all of them are doing well in $\mathrm{OL}$, despite the challenges of their first-time experiences. The problems these students experienced, either they are from B40 group or non-B40 group, are mostly on the internet connection and internet data. Therefore, there is a need for our government to step in and act toward providing all Malaysians with ultrafast and affordable broadband services, regardless of where they are.

\section{Acknowledgements}

Authors appreciates all those who participated in the study and Universiti Teknologi MARA, Cawangan Pulau Pinang who helped to falicitate the research process.

\section{Corresponding Author}

Siti Nurleena Abu Mansor

Department of Computer and Mathematical Sciences, Universiti Teknologi MARA, Cawangan Pulau Pinang, Kampus Permatang Pauh, 13500 Pulau Pinang, MALAYSIA.

Email: sitin140@uitm.edu.my

\section{References}

Amir, L. R., Tanti, I., Maharani, D. A., Wimardhani, Y. S., Julia, V., Sulijaya, B., \& Puspitawati, R. (2020). Student perspective of classroom and distance learning during COVID-19 pandemic in the undergraduate dental study program Universitas Indonesia. BMC medical education, 20(1), 1-8.

Appolloni, A., Colasanti, N., Fantauzzi, C., Fiorani, G., \& Frondizi, R. (2021). Distance Learning as a Resilience Strategy during Covid-19: An Analysis of the Italian Context. Sustainability, 13(3), 1388.

Arumugam, T. (2020). Ensure no kid is left out in e-learning. New Straits Times.

Bloom, B. S. (1956). Taxonomy of educational objectives. Vol. 1: Cognitive domain. New York: McKay, 20-24.

Brindley, J. (1995). Learners and learner services: The key to the future in open distance learning. Why the information highway, 102, 125.

Chin, B. M., Hwa, Y. S., \& Eam, L. H. (2020). INCOME AND SUBJECTIVE WELL-BEING: A CASE STUDY. Kajian Malaysia: Journal of Malaysian Studies, 38(2).

Cleveland-Innes, M., \& Campbell, P. (2012). Emotional Presence, Learning, and the Online Learning Environment. International Review of Research in Open and Distance Learning. 13. 269-292. doi: 10.19173/irrodl.v13i4.1234.

Coman, C., Țîru, L. G., Meseșan-Schmitz, L., Stanciu, C., \& Bularca, M. C. (2020). Online teaching and learning in higher education during the coronavirus pandemic: Students' 
perspective. Sustainability (Switzerland), 12(24), 1-22.

https://doi.org/10.3390/su122410367

Daniel, J. (2020). Education and the COVID-19 pandemic. Prospects, 49(1), 91-96.

Department of Statistics Malaysia. (2020). Press Release: Key Statistics of Labour Force in Malaysia, March 2020. Access online on $23^{\text {rd }}$ March 2021. https://www.dosm.gov.my/v1/index.php?r=column/cthemeByCat\&cat=124\&bul_id=Y 3NVdE44azFHbzkyeFlaWGF2ZER6Zz09\&menu_id=U3VPMIdoYUxzVzFaYmNkWXZteGd uZz09\#: :text=Unemployment\%20rate\%20increased\%20to\%203.9,increased\%20to\%2 03.9\%20per\%20cent

Firat, M., \& Bozkurt, A. (2020). Variables affecting online learning readiness in an open and distance learning university. Educational Media International, 57(2), 112-127.

Garbe, A., Ogurlu1, U., Logan, N. \& Cook, P. (2020). COVID-19 and Remote Learning: Experiences of Parents with Children during the Pandemic. American Journal of Qualitative Research, 4(3), 45-65.

Ghosh, S. (2012). Open and Distance Learning (ODL) Education System-Past, Present and Future-A Systematic Study of an Alternative Education System. Journal of Global Research in Computer Science, 3(4), 53-57.

Hart, C. (2012). Factors Associated with Student Persistence in an Online Program of Study: A Review of the Literature. Journal of Interactive Online Learning. 11. 19-42.

Huang, R., Tlili, A., Chang, T. W., Zhang, X., Nascimbeni, F., \& Burgos, D. (2020). Disrupted classes, undisrupted learning during COVID-19 outbreak in China: application of open educational practices and resources. Smart Learning Environments, 7(1), 1-15.

Internet allowance for B40 group is vital. (2020). New Straits Times. Available at: https://www.nst.com.my/opinion/letters/2020/06/599900/internet-allowance-b40group-vital (accessed on 25 March 2021).

Ivankova, N., \& Stick. (2007). Students' persistence in a distributed doctoral program in education leadership in higher education: A mixed methods study. Research in Higher Education, 93-135.

Jena, P. K. (2020). Impact of pandemic COVID-19 on education in India. International Journal of Current Research (IJCR), 12.

Kim, J., \& Lee, W. (2011). Assistance and possibilities: Analysis of learning-related factors affecting the online learning satisfaction of underprivileged students. Computers and Education, 57(4), 2395-2405. https://doi.org/10.1016/j.compedu.2011.05.021

Lassoued, Z., Alhendawi, M., \& Bashitialshaaer, R. (2020). An exploratory study of the obstacles for achieving quality in distance learning during the COVID-19 pandemic. Education Sciences, 10(9), 232.

Lee, S. J., Srinivasan, S., Trail, T., Lewis, D., \& Lopez, S. (2011). Examining the relationship among student perception of support, course satisfaction, and learning outcomes in online learning. The Internet and Higher Education, 14(3), 158-163.

Makoe, M., \& Shandu, T. (2018). Developing a mobile app for learning english vocabulary in an open distance learning context. International Review of Research in Open and Distributed Learning, 19(4).

Marek, M. W., Chew, C. S., \& Wu, W. C. V. (2021). Teacher experiences in converting classes to distance learning in the COVID-19 pandemic. International Journal of Distance Education Technologies (IJDET), 19(1), 40-60. 
Mathew, V. N., \& Chung, E. (2020). University Students' Perspectives on Open and Distance Learning (ODL) Implementation Amidst COVID-19. Asian Journal of University Education, 16(4), 152-160.

Mavromatis, A., Da Silva, A. P., Kondepu, K., Gkounis, D., Nejabati, R., \& Simeonidou, D. (2018, July). A software defined device provisioning framework facilitating scalability in internet of things. In 2018 IEEE $5 G$ World Forum (5GWF) (pp. 446-451). IEEE.

Mbatha, B. T., \& Naidoo, L. (2010). Problems hampering the collapse of distance in ODL. Progressio, 32(1), 170-184.

Moore, J. L., Dickson-Deane, C., \& Galyen, K. (2011). e-Learning, online learning, and distance learning environments: Are they the same?. The Internet and higher education, 14(2), 129-135.

Musingafi, M. C., Mapuranga, B., Chiwanza, K., \& Zebron, S. (2015). Challenges for open and distance learning (ODL) students: Experiences from students of the Zimbabwe Open University. Journal of Education and Practice, 6(18), 59-66.

Müller, T. (2008). Persistence of Women in Online Degree-Completion Programs. The International Review of Research in Open and Distributed Learning, 9(2). https://doi.org/10.19173/irrodl.v9i2.455

Nambiar, D. (2020). The impact of online learning during COVID-19: students' and teachers' perspective. The International Journal of Indian Psychology, 8(2), 783-793.

Nordin, R. (2021). 'Act fast to help poor students without e-learning devices'. The Star. https://www.thestar.com.my/metro/metro-news/2021/02/17/act-fast-to-help-poorstudents--without-e-learning-devices

Pityana, N. B. (2009). Open distance learning in the developing world: Trends, progress and challenges.

Virtic, P. M., Dolenc, K., \& Šorgo, A. (2021). Changes in Online Distance Learning Behaviour of University Students during the Coronavirus Disease 2019 Outbreak, and Development of the Model of Forced Distance Online Learning Preferences. European Journal of Educational Research, 10(1), 393-411.

Rahmadian, R., \& Maksum, H. (2021). The Contribution of Family Environment and Learning Motivation Toward Students' Learning Outcomes in Online Learning. Journal of Education Technology, 4(4), 385-391.

Ramli, M. F., Majid, M., \& Badyalina, B. (2020). Impeding Factors Towards the Effectiveness of Online Learning During Covid-19 Pandemic among Social Sciences Students. International Journal of Learning and Development, 10(4), 37.

Rolé, S. (2014). An inquiry into factors affecting the online learning experiences of A-level chemistry students studying in a blended learning course in a college in Malta and the impact of these experiences on learning identity (Doctoral thesis). The University of Nottingham. Nottingham UK. http://eprints.nottingham.ac.uk/14511/

Selvaras, J. (2020). Technology usage for teaching and learning law in open and distance learning: a Sri Lankan perspective. Asian Association of Open Universities Journal.

Swart, A. J. (2015). Student usage of a learning management system at an open distance learning institute: A case study in electrical engineering. International Journal of Electrical Engineering Education, 52(2), 142-154.

Thompson, E., Luxton-Reilly, A., Whalley, J. L., Hu, M., \& Robbins, P. (2008). Bloom's taxonomy for CS assessment. In Proceedings of the tenth conference on Australasian computing education-Volume 78 (pp. 155-161). 
UNESCO Institute. (2020). Guidance on active learning at home during educational disruption: promoting student's self-regulation skills during COVID-19 outbreak. Available at: https:// iite.unesco.org/publications/guidance-on-active-learning-at-home-duringeducational-disruption/ (accessed on 25 March 2021).

Yang, D., Baldwin, S., \& Snelson, C. (2017). Persistence factors revealed: students' reflections on completing a fully online program. Distance Education. 38. 23-36. 10.1080/01587919.2017.1299561.

Zhao, Y., Guo, Y., Xiao, Y., Zhu, R., Sun, W., Huang, W., Liang, D., Tang, L., Zhang, F., Zhu, D., \& $\mathrm{Wu}$, J. L. (2020). The Effects of Online Homeschooling on Children, Parents, and Teachers of Grades 1-9 During the COVID-19 Pandemic. Medical science monitor: international medical journal of experimental and clinical research, 26, e925591. https://doi.org/10.12659/MSM.925591 